\title{
Effect of Surface Applied Organic and Inorganic Corrosion Inhibitors on Reinforced Steel in Concrete
}

\author{
Nishant Kumar, Bisakha Chalisey, Sunil Saharan, Megha Gupta
}

\begin{abstract}
This paper presents the results of an experimental investigation carried out to study the effect of surface applied organic and inorganic corrosion inhibitors on reinforced steel in concrete. The reinforcement bars were coated with Neem powder (organic inhibitor) and Zinc powder (inorganic inhibitor) as corrosion inhibitors. The samples of beams of size $100 \times 100 \times 640 \mathrm{~mm}$ having 4 steel bars as reinforcement were prepared and cured in normal water for 15 days and in saline environment for 42 days. The inhibitors were applied in the form of 2 coats, 4 coats and blend of both. The grade of concrete used was M30. Half-cell Potential and Weight loss measurements were carried out to determine the efficiency of corrosion inhibitors [11]. The corrosion inhibition efficiency of controlled specimen and coated specimens were compared. From the results it was seen that samples with 4 coats of Neem showed $44 \%$ inhibition efficiency as compared to control specimens. Similarly specimens with two coats of Neem, four coats of Neem and Zinc also showed better corrosion inhibition efficiency. Highest weight loss was observed in case of control specimen. The study concludes that use of surface applied corrosion inhibitors prove efficient in enhancing the corrosion inhibition efficiency of concrete. Surface applied corrosion inhibitors provide protective layer to the reinforcement thereby protecting it from corrosion and increasing the durability of the structure. This type of technique of using corrosion inhibitors in concrete can be used in various structures such as buildings, bridges, sewage pipes, marine structures, abutments \& piers, RCC roads which are subjected to harsh environmental conditions.
\end{abstract}

Keywords: Corrosion inhibitors, Half-Cell Potential, Reinforced Concrete, Neem powder, Zinc powder

\section{INTRODUCTION}

In today's world, the major issue in the construction of massive structures is corrosion. It has become a huge problem worldwide in every kind of construction activity.

Revised Manuscript Received on December 30, 2019.

* Correspondence Author

Nishant Kumar*, Department of Civil Engineering, Sharda University, Greater Noida, India. Email: nishant.kumar4@sharda.ac.in

Bisakha Chalisey, Department of Civil Engineering, Sharda University, Greater Noida, India. Email: v.chalisey@gmail.com

Sunil Saharan, Department of Civil Engineering, Sharda University, Greater Noida, India. Email: sunil.saharan@sharda.ac.in

Megha Gupta, Department of Civil Engineering, Sharda University, Greater Noida, India. Email: megha.gupta@sharda.ac.in

(C) The Authors. Published by Blue Eyes Intelligence Engineering and Sciences Publication (BEIESP). This is an open access article under the CC BY-NC-ND license (http://creativecommons.org/licenses/by-nc-nd/4.0/)
Corrosion is the worsening of metal by chemical attack or reaction with its environment [1]. It is a constant and continuous problem, often difficult to eliminate completely. Prevention would be more practical and achievable than complete elimination [1,13]. Corrosion processes develop fast after disruption of the protective barrier and are accompanied by a number of reactions that change the composition and properties of both the metal surface and the local environment, for example, formation of oxides, and diffusion of metal cations into the coating matrix, local $\mathrm{pH}$ changes, and electrochemical potential $[1,14]$. Inorganic and organic inhibitors are the two main types of corrosion inhibitors. Inorganic inhibitors, such as nitrite, nitrate, chromate, dichromate, phosphate are widely used for various metals. Today, there has been an increasing search for green corrosion inhibitors, due to the toxic behavior of some inhibitors. Green corrosion inhibitors are biodegradable and free of heavy metals or other toxic compounds [2, 4]. Green corrosion inhibitors, also known as organic inhibitors are the compounds containing one or more polar groups (with $\mathrm{O}, \mathrm{N}$, $\mathrm{P}, \mathrm{S}$ atoms, and $\pi$ electrons), which are effective to prevent corrosion via adsorption on the metal surface [3]. One well known example of corrosion is rusting of metals. To prevent the material or metal from corrosion, inhibitors are used. Inhibitors are those substances which in low concentration and relatively aggressive environment help prevent or minimize the corrosion $[4,5]$.

There are various methods of incorporating corrosion inhibitors in concrete. Among the different methods available, the application of surface applied corrosion inhibitors on steel reinforcement bars embedded in concrete is relatively a newer concept. The mechanism of the inhibitor is that it is chemically adsorbed on the surface of the metal and forms a thin protective layer with inhibitor effect or by combination between inhibitor ions and metallic surface [4]. Also, the inhibitor may react with a potentially corrosive component present in the aqueous media and the product is a complex and also leads to form a film by oxide protection of the base material [6]. Previously, there has been whole lot of research on surface-applied corrosion inhibitors (SACI) directly applied to existing concrete structures which has been suffered by corrosion due to mostly chloride attacks. Similarly, many researchers have studies the effect of corrosion inhibitors when directly mixed in the mixing process of fresh concrete.

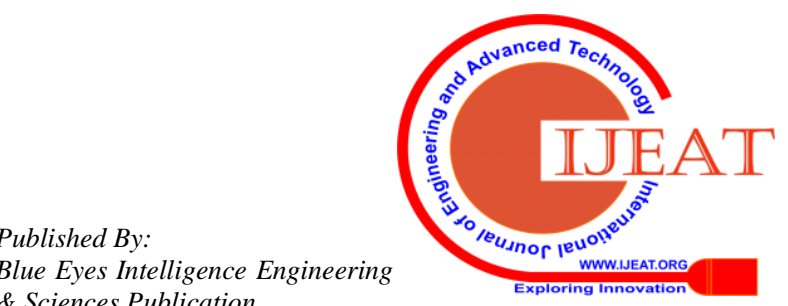


This paper reviews the corrosion inhibitor, corrosion prevention process and the recent advances on the inhibiting effect of various green corrosion inhibitors on steel reinforcement bars embedded in concrete. This paper presents the use of organic and inorganic corrosion inhibitors.

\section{METHODOLOGY}

In the present experimental work, the inhibitors were used in the form of coats applied on the Rebar. The grade of concrete used was M30. To check the grade of concrete compressive strength of cubes was tested. Further to check the effect of corrosion inhibitors Half-cell potential and Weight loss measurements were carried out [7, 8]. These are the direct methods for checking the rate of corrosion Increase in weight loss shows the degradation of bras. Beam specimens of size 100x100x640mm were used. The specimens were cured in normal water for 15 days and for 42 days in saline environment. Half-cell potential readings were taken after an interval of 7 days. Neem powder and Zinc powder were used as inhibitors.

\section{EXPERIMENTAL PROGRAMME}

\section{A. Material Used}

The materials used include cement, fine aggregates, coarse aggregates, water and steel bars. Each material was tested \& its physical properties are described below.

Cement: Ordinary Portland cement of grade 43 is used in the present investigation. Birla ultra-cement from a local dealer is used. The tests conducted on the cement are performed as per IS: 8112-1989 and IS 4031:1963 specifications. Weight of sample taken was 300gms.

Table-I Properties of Cement

\begin{tabular}{|c|c|c|c|}
\hline S.NO. & Properties & $\begin{array}{c}\text { Values } \\
\text { obtained }\end{array}$ & $\begin{array}{c}\text { Standard } \\
\text { values }\end{array}$ \\
\hline 1 & Consistency & $30 \%$ & - \\
\hline 2 & Initial Setting Time & 51 minutes & $\begin{array}{c}\text { Not less than } 30 \\
\text { minutes }\end{array}$ \\
\hline 3 & Final Setting Time & 386 minutes & $\begin{array}{c}\text { Not greater than } \\
600 \text { minutes }\end{array}$ \\
\hline 4 & Fineness & $5 \%$ & Less than $10 \%$ \\
\hline 5 & Specific gravity & 3.12 & - \\
\hline
\end{tabular}

Fine Aggregates: Fine aggregates consist of natural Yamuna river sand conforming to grading zone III. The sieve analysis was performed as per IS 383:1970. The results are presented in Table II. Weight of sample taken was 1000 gm for sieve analysis and $500 \mathrm{gm}$ for specific gravity and water absorption.

Table-II Properties of sand

\begin{tabular}{|c|c|c|}
\hline S.NO. & Properties & $\begin{array}{c}\text { Values } \\
\text { obtained }\end{array}$ \\
\hline 1 & Specific gravity & 2.6 \\
\hline 2 & Water absorption & $1 \%$ \\
\hline 3 & Fineness modulus & 2.3 \\
\hline 4 & Grading Zone & III \\
\hline
\end{tabular}

Coarse Aggregates: Coarse aggregates consist of locally available crushed aggregates of nominal size $20 \mathrm{~mm}$. The testing of aggregates was done as per IS 383:1970 and IS 2386:1963. The results are shown in table 3.

Table-III Properties of coarse aggregates

\begin{tabular}{|c|c|c|}
\hline S.NO. & Properties & Values obtained \\
\hline 1 & Type of aggregates & Crushed \\
\hline 2 & Specific gravity & 2.63 \\
\hline 3 & Water absorption & $0.70 \%$ \\
\hline 4 & Fineness modulus & 3.23 \\
\hline
\end{tabular}

Water: Tap water free from dirt, dust and any other impurities with $\mathrm{pH} 7.6$ is used throughout the experimental work. The quality of water was tested as per Indian standard. Super plasticizer: Conmix 777, sulphonated naphthalene formaldehyde (SNF) based super plasticizer is used throughout the experimental work. It is a 2nd generation super plasticizer produced by oleum or SO3 Sulphonation of naphthalene. It is dark brown in color and is about half the cost of polycarboxylic ether super plasticizer.

Steel Reinforcement: TMT bars of diameter $10 \mathrm{~mm}$ and 640 mm length are used as reinforcement.

Corrosion inhibitors: The corrosion inhibition and adsorption properties of Neem extract inhibit Mild Steel corrosion [12]. Azadirachta Indica (Neem) powder and Zinc powder are used as inhibitors in the present research work. Neem powder is a fine powder obtained by grinding dried Neem leaves. The powder was brought from a verified supplier in zip lock packets. The powder is green in color with a specific gravity of 1.82. It falls under the category of Green Inhibitors containing numerous naturally occurring organic compounds. More than 300 compounds have been isolated from the plant and out of these, azadiractin, azadirone, gedunin, nimbin, nimbandiol, nimbolide, nimbolin, salannin, margolone, vilasanin, flavanoids and limonoids are considered as effective inhibitor complexes.

Zinc powder is another inhibitor used in this work. The powder was purchased from a verified local supplier Shakti Metals claiming 65\% zinc content. Zinc coating is applied in various forms to prevent steel from corrosion, but the same doesn't remain for a long time, allowing the steel to come in contact with ingredients taking part in rusting. My approach is same, by using zinc powder in the form of 2-4 coats applied on the steel bars. 


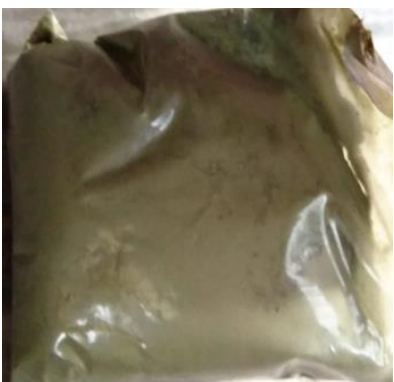

a)

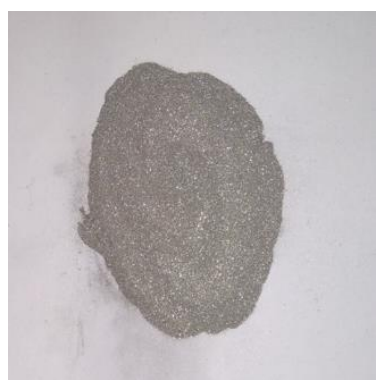

b)
Fig. 1.a) Neem Powder b) Zinc Powder

\section{B. Concrete Mix Design}

The proportioning of concrete mix design was done as per Indian Standard 10262:2009. With a water-cement ratio of 0.43 and superplasticizer percentage of 0.8 the ratio of 1:1.29:2.44 was obtained. The workability of the desired mix was obtained by using Conmix 777, a Sulphonated Naphthalene Formaldehyde (SNF) based superplasticizer. The slump achieved was $96 \mathrm{~mm}$.

\begin{tabular}{|c|c|}
\hline Material & Quantity \\
\hline Grade & M30 \\
\hline Cement & 458 \\
\hline Fine aggregate & 595 \\
\hline Coarse aggregate & 1118 \\
\hline Water & 197 \\
\hline Water/cement ratio & 0.43 \\
\hline
\end{tabular}

\section{Casting and Curing of Specimens}

In the present research work, four beam moulds of size $100 \mathrm{x}$ $100 \times 640 \mathrm{~mm}$ were fabricated for the casting of specimens. A total of 14 specimens were casted for the experimental procedure. At the time of casting, the interior of mould is lubricated so that the specimens can be easily removed after 24 hours. Two bars are placed in each specimen with a cover of $20 \mathrm{~mm}$ from sides and $20 \mathrm{~mm}$ cover from the bottom of the mould. After filling the mould with a layer of concrete up to $20 \mathrm{~mm}$, the steel bars are then placed and the rest of the mould is filled to the top with proper compaction.

After 24 hours of casting the specimens are carefully removed from the mould. The specimens are then cured in potable water for 20 days. After normal curing period the specimens are shifted to saline tank containing $3.5 \% \mathrm{NaCl}$ solution for further curing [10]. This is done so the chloride ions will penetrate the concrete surface reaching for the steel bars thereby initiating corrosion.

\section{Testing of Specimen}

Test methods include the tests of fresh concrete mix for workability and hardened concrete specimens for compressive strength test. For corrosion measurements Half Cell potentiometer was used, also weight loss measurements were taken at the end of test.:

\section{Slump Test and Compaction Factor Test}

Table IV Mix proportions per cubic meter

Slump test and compaction factor test were done as per IS-1199: (1959) in order to measure the workability of concrete mixes.

\section{Compressive Strength Test}

Compressive strength test is performed on cubes of size 150 x 150 x $150 \mathrm{~mm}$ as per IS 516: 1959. The mold is cleaned properly and lubricated. Concrete is filled in 3 layers and each layer is tamped with not less than 35 strokes per layer. The cubes are then stored in a place free from vibration for 24 hours. The cubes are then removed from the molds and marked. The specimens are then cured in curing tanks for a period of 28 days. At the time of testing the specimens are wiped with clean cloth to remove any impurity and brought to saturated surface dry condition. The specimens are then placed on Compression-testing machine (2000 KN Capacity) and load is applied at a rate of $140 \mathrm{~kg} / \mathrm{cm} 2 / \mathrm{min}$ till the specimen fails. The average failure of three specimens is taken as representative compressive strength of mix.

\section{Corrosion Monitoring}

In the present research work, the corrosion behavior of steel bars was evaluated by Half-Cell potentiometer and Weight Loss method. For predicting the service life of Reinforced Concrete structures and to establish the need of repair and rehabilitation, NDT (Non-Destructive techniques) should be used to assess the corrosion rate and activity of the steel bars. Electrochemical method will be used to evaluate the corrosion rate of steel bars.

\section{RESULTS AND DISCUSSIONS}

\section{A. Tests on Fresh Concrete}

\section{Slump Test}

In order to achieve slump between $75-100 \mathrm{~mm}$ various percentages of super plasticizer was used. The target slump was achieved at $0.8 \%$.

\section{Table V Workability Test}

\begin{tabular}{|c|c|c|c|c|}
\hline Conmix 777 \% & 0.40 & 0.50 & 0.65 & 0.80 \\
\hline & & & & \\
Slump & $10 \mathrm{~mm}$ & $25 \mathrm{~mm}$ & $45 \mathrm{~mm}$ & $93 \mathrm{~mm}$ \\
\hline
\end{tabular}

\section{Compaction Factor Test}

The results of compaction factor are shown in table 6

Table VI Compaction Factor Results

\begin{tabular}{|c|c|}
\hline Mix & Compaction factor \\
\hline & \\
Control specimen & 0.85 \\
\hline
\end{tabular}

\section{B. Tests on Hardened Concrete}

\section{Compressive Strength Test}

The compressive strength test was performed on compressive strength testing machine. The average 28 days compressive strength of 3 cubes was found to be $38 \mathrm{~N} / \mathrm{mm}^{2}$

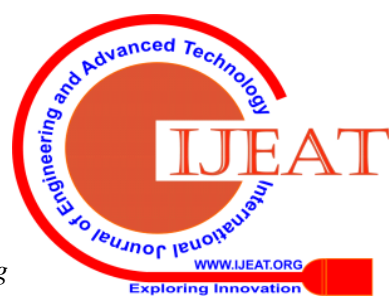




\section{Corrosion Measurements}

\section{Half-Cell Potential Measurements}

The most useful variable measured in corrosion monitoring is the potential of corroding metal i.e. $E_{\text {corr }}$ The difference in voltage between rebar with concrete around it and a reference electrode gives the corrosion potential $[7,8]$. Half-cell potentiometer consisting of copper sulphate half-cell as reference electrode is used to monitor the corrosion potential in the present research work. The instrument gives the readings in mili-Volts.

Lesser the voltage less will be the corrosion potential and hence the risk of metal getting corroded is less and vice versa. The corrosion potential readings are taken after every 7 days while the specimens are in saline curing. The graphs below present the corrosion potential verses the exposure in days for concrete specimens with and without coated bars cured in $3.5 \% \mathrm{NaCl}$ solution.

Table VII Half Cell Potential of Control specimens(mV)

\begin{tabular}{|c|c|c|c|c|c|c|}
\hline $\begin{array}{c}\text { Number } \\
\text { of Days }\end{array}$ & $\mathbf{7}$ & $\mathbf{1 4}$ & $\mathbf{2 1}$ & $\mathbf{2 8}$ & $\mathbf{3 5}$ & $\mathbf{4 2}$ \\
\hline Bar 25 & -101 & -218 & -310 & -420 & -505 & -600 \\
\hline Bar 28 & -103 & -215 & -307 & -417 & -502 & -597 \\
\hline Bar 26 & -105 & -216 & -297 & -402 & -510 & -603 \\
\hline Bar 27 & -108 & -214 & -300 & -406 & -512 & -608 \\
\hline
\end{tabular}

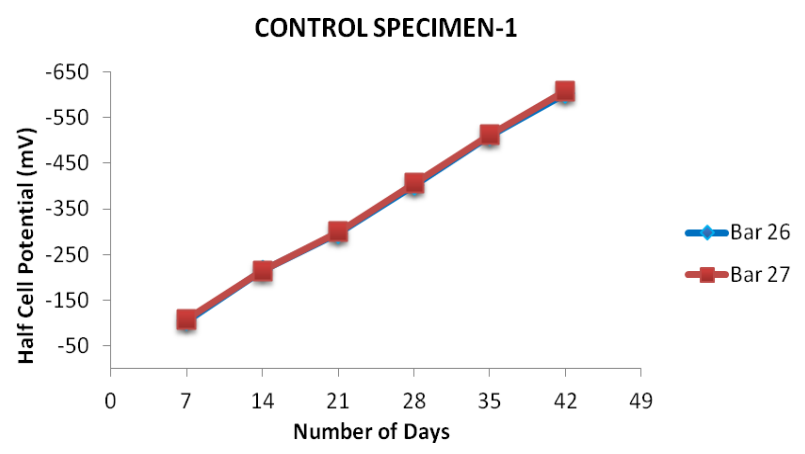

Fig. 2.Half-Cell Potential of Control Specimen

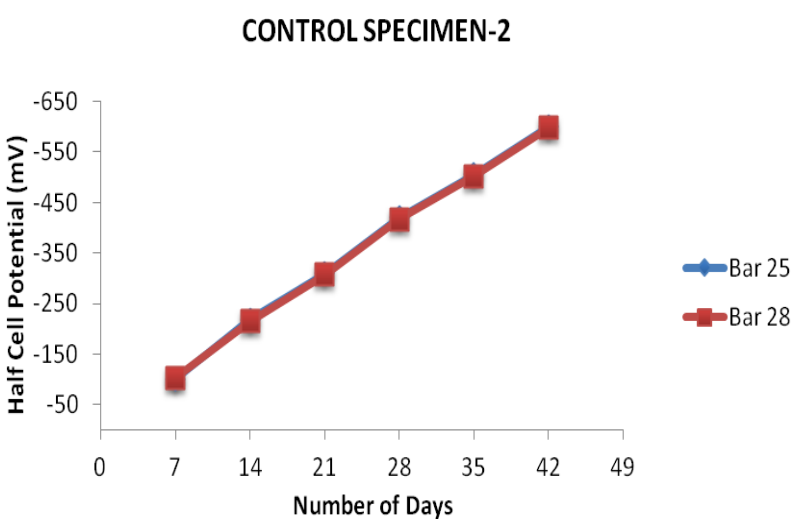

Fig. 3. Half-Cell Potential of Control Specimen

In Fig. 2 \& 3, the half-cell potential of control specimens is plotted showing weekly variation of the curve. The potential went on increasing as the bars are not coated with any inhibitor.

Table VIII Half-cell potential of specimen with 2 coats of Neem

\begin{tabular}{|c|c|c|c|c|c|c|}
\hline $\begin{array}{c}\text { Number } \\
\text { of days }\end{array}$ & $\mathbf{7}$ & $\mathbf{1 4}$ & $\mathbf{2 1}$ & $\mathbf{2 8}$ & $\mathbf{3 5}$ & $\mathbf{4 2}$ \\
\hline Bar 1 & -103 & -173 & -211 & -268 & -344 & -402 \\
\hline Bar 2 & -106 & -175 & -213 & -271 & -347 & -406 \\
\hline
\end{tabular}

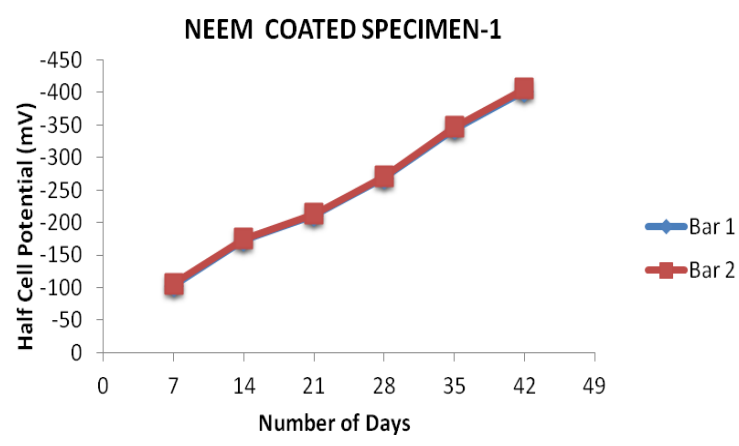

Fig. 4.Half-Cell Potential of Neem coated specimen with 2 coats of Neem

In Fig. 4, the half-cell potential of Neem coated specimen is plotted with 2 coats of Neem applied on rebar as inhibitor.

Table IX Half-cell potential of specimen with 2 coats of Neem

\begin{tabular}{|c|c|c|c|c|c|c|}
\hline $\begin{array}{c}\text { Number } \\
\text { of days }\end{array}$ & $\mathbf{7}$ & $\mathbf{1 4}$ & $\mathbf{2 1}$ & $\mathbf{2 8}$ & $\mathbf{3 5}$ & $\mathbf{4 2}$ \\
\hline Bar 3 & -101 & -166 & -204 & -261 & -337 & -400 \\
\hline Bar 4 & -104 & -162 & -201 & -258 & -334 & -398 \\
\hline
\end{tabular}

\section{NEEM COATED SPECIMEN-2}

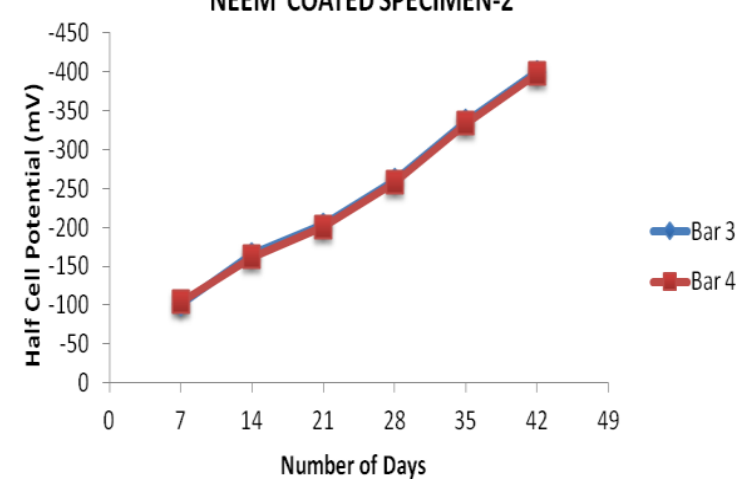

Fig. 5.Half-Cell Potential of Neem coated specimen with 2 coats of Neem 
Table X Half-cell potential of specimen with 4 coats of Neem

\begin{tabular}{|c|c|c|c|c|c|c|}
\hline $\begin{array}{c}\text { Number } \\
\text { of days }\end{array}$ & $\mathbf{7}$ & $\mathbf{1 4}$ & $\mathbf{2 1}$ & $\mathbf{2 8}$ & $\mathbf{3 5}$ & $\mathbf{4 2}$ \\
\hline Bar 5 & -102 & -154 & -192 & -238 & -278 & -334 \\
\hline Bar 6 & -105 & -156 & -197 & -243 & -281 & -337 \\
\hline
\end{tabular}

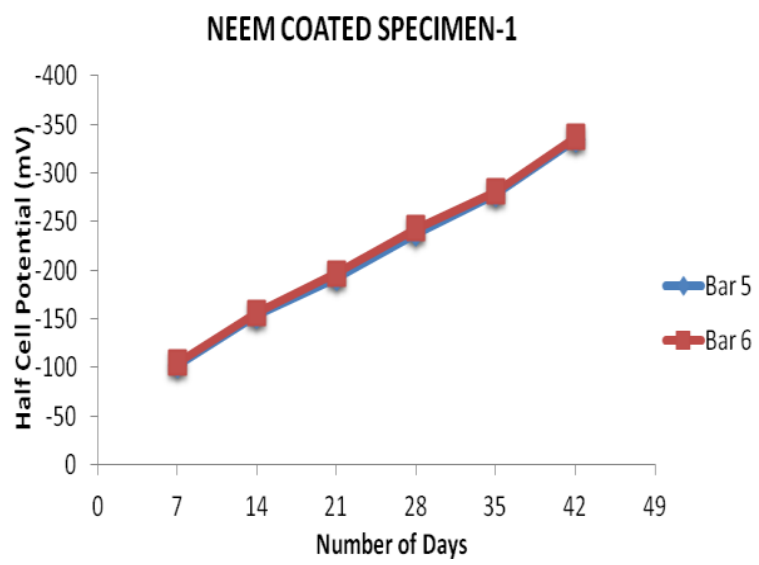

Fig. 6.Half-Cell Potential of Neem coated specimen with 4 coats of Neem

Table XI Half cell potential of specimen with 4 coats of Neem

\begin{tabular}{|c|c|c|c|c|c|c|}
\hline $\begin{array}{c}\text { Number } \\
\text { of days }\end{array}$ & $\mathbf{7}$ & $\mathbf{1 4}$ & $\mathbf{2 1}$ & $\mathbf{2 8}$ & $\mathbf{3 5}$ & $\mathbf{4 2}$ \\
\hline Bar 7 & -100 & -145 & -191 & -235 & -287 & -342 \\
\hline Bar 8 & -98 & -141 & -187 & -231 & -283 & -339 \\
\hline
\end{tabular}

\section{NEEM COATED SPECIMEN-2}

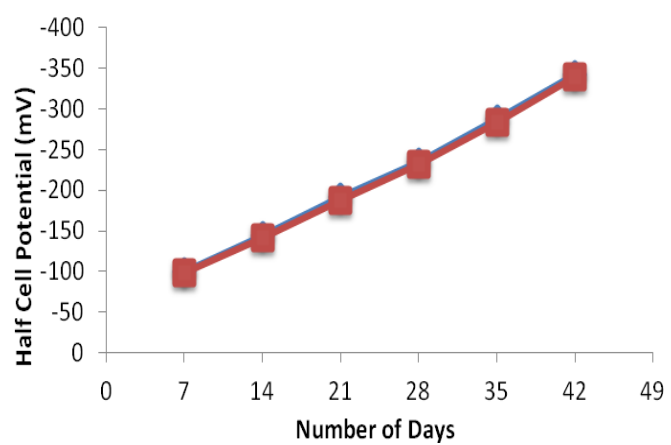

Fig. 7. Half-Cell Potential of Neem coated specimen with 4 coats of Neem

In Fig. $6 \& 7$, the half-cell potential of Neem coated specimens is plotted. The reinforcing bars are coated with 4-coats of Neem powder as inhibitor.

Retrieval Number: B4092129219/2019@BEIESP

DOI: 10.35940/ijeat.B4092.129219

Journal Website: www.ijeat.org
Table XII Half-cell potential of specimen with 2 coats of Zinc

\begin{tabular}{|c|c|c|c|c|c|c|}
\hline $\begin{array}{c}\text { Number } \\
\text { of days }\end{array}$ & $\mathbf{7}$ & $\mathbf{1 4}$ & $\mathbf{2 1}$ & $\mathbf{2 8}$ & $\mathbf{3 5}$ & $\mathbf{4 2}$ \\
\hline Bar 9 & -237 & -307 & -376 & -447 & -517 & -587 \\
\hline Bar 11 & -234 & -304 & -372 & -443 & -514 & -583 \\
\hline
\end{tabular}

\section{ZINC COATED SPECIMEN-1}

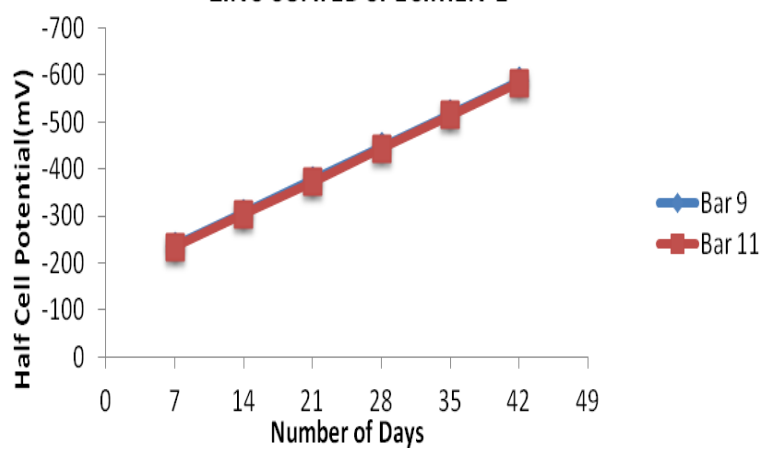

Fig. 8.Half-Cell Potential of Zinc coated specimen with 2 coats of Zinc

Table XIII Half cell potential of specimen with 2 coats of Zinc

\begin{tabular}{|c|c|c|c|c|c|c|}
\hline $\begin{array}{c}\text { Number } \\
\text { of days }\end{array}$ & $\mathbf{7}$ & $\mathbf{1 4}$ & $\mathbf{2 1}$ & $\mathbf{2 8}$ & $\mathbf{3 5}$ & $\mathbf{4 2}$ \\
\hline Bar 10 & -231 & -302 & -373 & -441 & -512 & -581 \\
\hline Bar 12 & -229 & -298 & -369 & -438 & -507 & -578 \\
\hline
\end{tabular}

\section{ZINCCOATEDSPECIMEN-2}

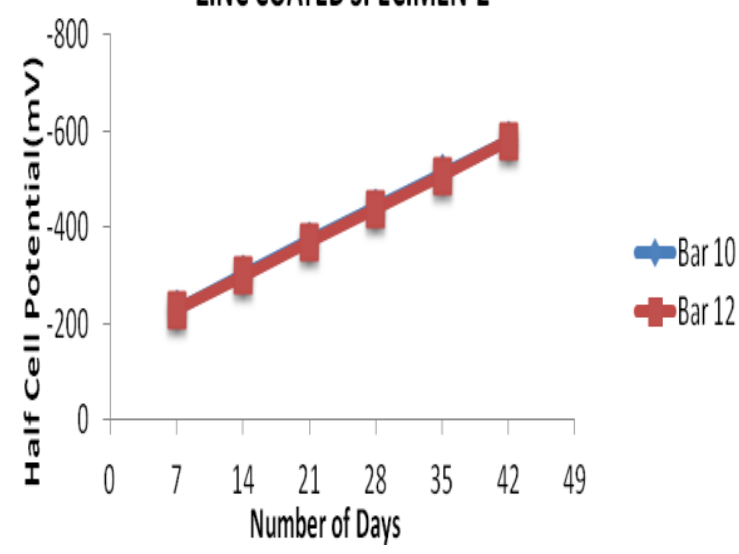

Fig. 9.Half-Cell Potential of Zinc coated specimen with 2 coats of Zinc

In Fig. 8 \& 9, the half-cell potential of Zinc coated specimens is plotted. The bars are coated with 2-coats of Zinc powder as inhibitor.

Published By:

Blue Eyes Intelligence Engineering \& Sciences Publication 
Table XIV Half-cell potential of specimen with 4 coats of Zinc

\begin{tabular}{|c|c|c|c|c|c|c|}
\hline $\begin{array}{c}\text { Number } \\
\text { of days }\end{array}$ & $\mathbf{7}$ & $\mathbf{1 4}$ & $\mathbf{2 1}$ & $\mathbf{2 8}$ & $\mathbf{3 5}$ & $\mathbf{4 2}$ \\
\hline Bar 13 & -262 & -337 & -412 & -487 & -562 & -637 \\
\hline Bar 14 & -259 & -334 & -408 & -484 & -558 & -634 \\
\hline
\end{tabular}

\section{ZINC COATED SPECIMEN-1}

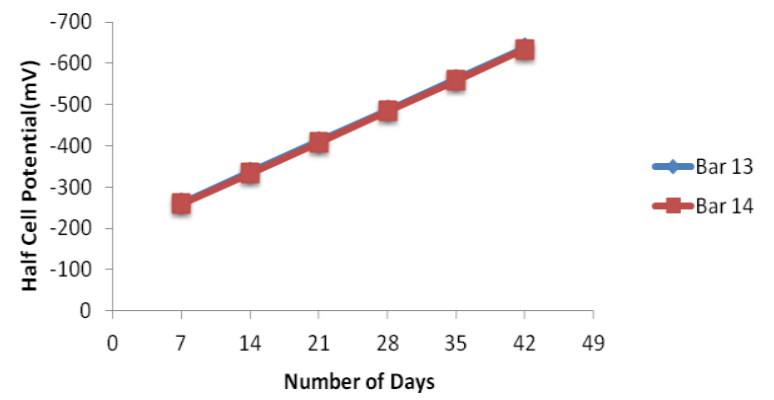

Fig. 10. Half-Cell Potential of Zinc coated specimen with 4 coats of Zinc

Table XV Half cell potential of specimen with 4 coats of Zinc

\begin{tabular}{|c|c|c|c|c|c|c|}
\hline $\begin{array}{c}\text { Number } \\
\text { of days }\end{array}$ & $\mathbf{7}$ & $\mathbf{1 4}$ & $\mathbf{2 1}$ & $\mathbf{2 8}$ & $\mathbf{3 5}$ & $\mathbf{4 2}$ \\
\hline Bar 15 & -264 & -339 & -416 & -489 & -566 & -641 \\
\hline Bar 16 & -267 & -341 & -418 & -492 & -568 & -643 \\
\hline
\end{tabular}

ZINC COATED SPECIMEN-2

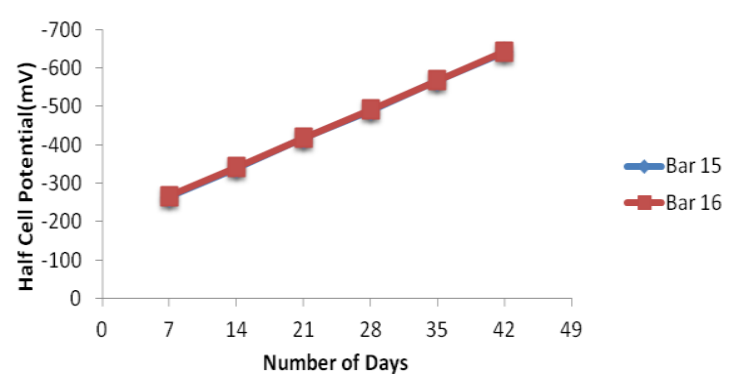

Fig. 11. Half-Cell Potential of Zinc coated specimen with 4 coats of Zinc

Table XVI Half-cell potential of specimen with 2 coats each of Neem and Zinc

\begin{tabular}{|c|c|c|c|c|c|c|}
\hline $\begin{array}{c}\text { Number } \\
\text { of days }\end{array}$ & $\mathbf{7}$ & $\mathbf{1 4}$ & $\mathbf{2 1}$ & $\mathbf{2 8}$ & $\mathbf{3 5}$ & $\mathbf{4 2}$ \\
\hline Bar 17 & -141 & -221 & -303 & -384 & -465 & -546 \\
\hline Bar 18 & -143 & -224 & -306 & -386 & -468 & -548 \\
\hline
\end{tabular}

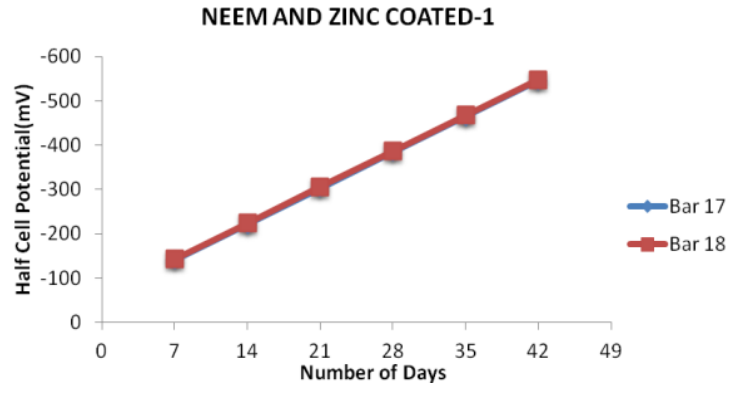

Fig. 12. Half-Cell Potential of Specimen with 2 coats each of Neem and Zinc

Table XVII Half-cell potential of specimen with 2 coats each of Neem and Zinc

\begin{tabular}{|c|c|c|c|c|c|c|}
\hline $\begin{array}{c}\text { Number } \\
\text { of days }\end{array}$ & $\mathbf{7}$ & $\mathbf{1 4}$ & $\mathbf{2 1}$ & $\mathbf{2 8}$ & $\mathbf{3 5}$ & $\mathbf{4 2}$ \\
\hline Bar 19 & -139 & -219 & -301 & -383 & -463 & -544 \\
\hline Bar 20 & -142 & -223 & -304 & -385 & -466 & -547 \\
\hline
\end{tabular}

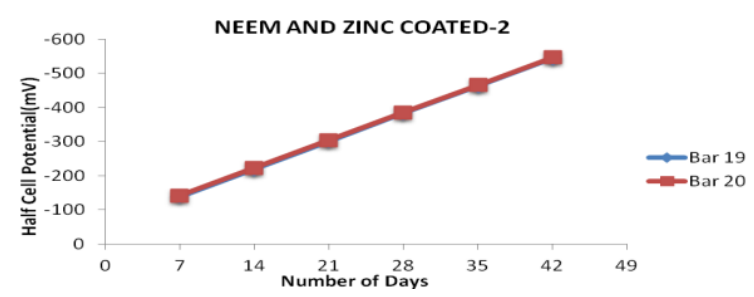

Fig. 13. Half-Cell Potential of Specimen with 2 coats each of Neem and Zinc

In Fig. 12 \& 13, the half-cell potential of Neem and Zinc coated specimens is plotted. The bars are coated with 2-coats each of Neem and Zinc powder as inhibitors.

Table XVIII Half-cell potential of specimen with 4 coats each of Neem and Zinc

\begin{tabular}{|c|c|c|c|c|c|c|}
\hline $\begin{array}{c}\text { Number of } \\
\text { days }\end{array}$ & $\mathbf{7}$ & $\mathbf{1 4}$ & $\mathbf{2 1}$ & $\mathbf{2 8}$ & $\mathbf{3 5}$ & $\mathbf{4 2}$ \\
\hline Bar 21 & -129 & -206 & -283 & -360 & -437 & -514 \\
\hline Bar 22 & -132 & -209 & -286 & -363 & -439 & -516 \\
\hline
\end{tabular}

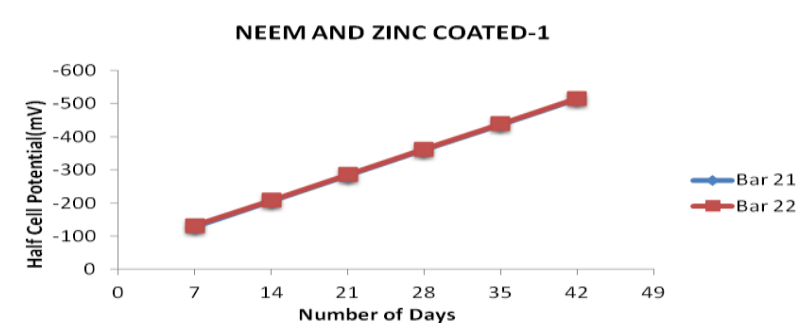

Fig. 14. Half-Cell Potential of Specimen with 4 coats each of Neem and Zinc

Published By:

Blue Eyes Intelligence Engineering \& Sciences Publication 
Table XIX Half-cell potential of specimen with 4 coats each of Neem and Zinc

\begin{tabular}{|c|c|c|c|c|c|c|}
\hline $\begin{array}{c}\text { Number of } \\
\text { days }\end{array}$ & $\mathbf{7}$ & $\mathbf{1 4}$ & $\mathbf{2 1}$ & $\mathbf{2 8}$ & $\mathbf{3 5}$ & $\mathbf{4 2}$ \\
\hline Bar 23 & -135 & -213 & -288 & -366 & -442 & -519 \\
\hline Bar 24 & -137 & -215 & -291 & -368 & -446 & -522 \\
\hline
\end{tabular}

NEEM AND ZINC COATED-2

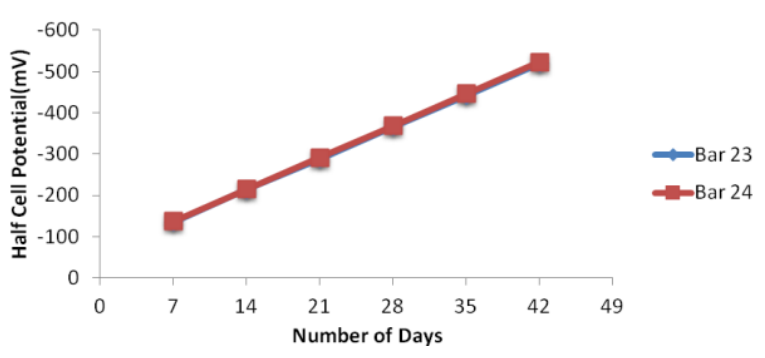

Fig. 15. Half-Cell Potential of Specimen with 4 coats each of Neem and Zinc

In Fig. 14 \& 15, the half-cell potential of Neem and Zinc coated specimens is plotted. The bars are coated with 4-coats each of Neem and Zinc as inhibitors
AVERAGE POTENTIAL OF SPECIMENS

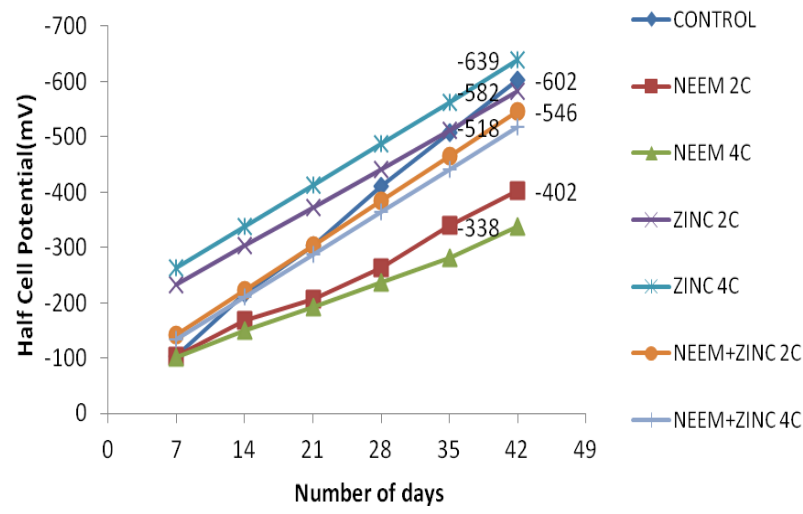

Fig. 16. Average Potential of Specimen

In Fig. 16 \& 17, a comparison between the average potential of specimens and 42 Days percentage inhibition is shown.

42 Days-Percentage Inhibition

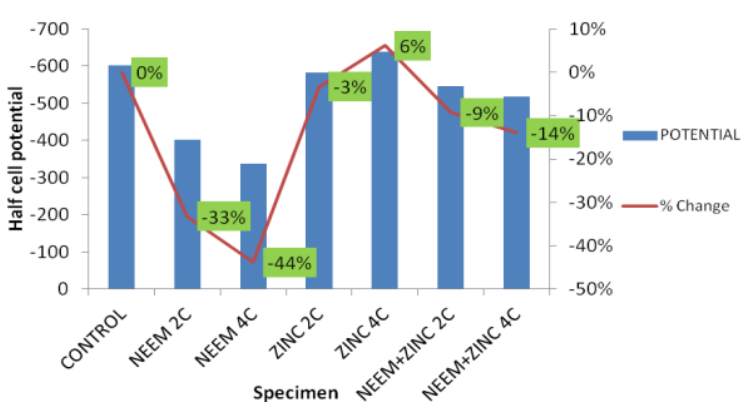

Fig. 17. Percentage Inhibition

Table XX Average potential of specimens

\begin{tabular}{|c|l|l|l|l|l|l|l|l|}
\hline \multirow{2}{*}{$\begin{array}{c}\text { Number of } \\
\text { days }\end{array}$} & \multicolumn{1}{|c|}{ Control } & \multicolumn{1}{c|}{$\begin{array}{c}\text { Neem } \\
\text { 2coats }\end{array}$} & $\begin{array}{c}\text { Neem } \\
\text { 4coats }\end{array}$ & Zinc 2coats & Zinc 4coats & \multicolumn{1}{c|}{$\begin{array}{c}\text { Neem+ } \\
\text { Zinc 2coats }\end{array}$} & $\begin{array}{c}\text { Neem+ }+ \\
\text { Zinc 4coats }\end{array}$ \\
\cline { 2 - 8 } & \multicolumn{7}{|c|}{ Half-cell potential(mv) } \\
\hline $\mathbf{7}$ & -104 & -103 & -101 & -233 & -263 & -141 & -133 \\
\hline $\mathbf{1 4}$ & -216 & -169 & -149 & -303 & -338 & -222 & -211 \\
\hline $\mathbf{2 1}$ & -303 & -207 & -192 & -372 & -413 & -303 & -287 \\
\hline $\mathbf{2 8}$ & -411 & -264 & -237 & -442 & -488 & -384 & -364 \\
\hline $\mathbf{3 5}$ & -507 & -340 & -282 & -512 & -563 & -465 & -441 \\
\hline $\mathbf{4 2}$ & -602 & -402 & -338 & -582 & -639 & -546 & -518 \\
\hline
\end{tabular}

Table XXI Percentage inhibition

\begin{tabular}{|c|l|l|l|l|l|l|l|}
\hline Specimen & \multicolumn{1}{|c|}{ Control } & \multicolumn{1}{|c|}{$\begin{array}{c}\text { Neem } \\
\text { 2c }\end{array}$} & \multicolumn{1}{|c|}{$\begin{array}{c}\text { Neem } \\
\text { 4c }\end{array}$} & \multicolumn{1}{|c|}{$\begin{array}{c}\text { Zinc } \\
\text { 2c }\end{array}$} & $\begin{array}{c}\text { Zinc } \\
\text { 4c }\end{array}$ & $\begin{array}{c}\text { Neem+zinc } \\
\text { 2c }\end{array}$ & 4c \\
\hline $\begin{array}{c}\text { Half cell } \\
\text { potential }\end{array}$ & -602 & -402 & -338 & -582 & -639 & -546 & -518 \\
\hline \% Change & 0 & -0.332 & -0.438 & -0.033 & 0.0614 & -0.09302 & -0.13953 \\
\hline
\end{tabular}

tabulated form:

\section{Weight Loss Measurements}

- The reinforcing bars were weighed before use. The specimens were crushed by using CTM after completion of experiment. The bars were taken out with care and each bar was cleaned with the help of emery paper. Weight of each bar was taken separately. The results are presented in 
Effect of Organic and Inorganic Corrosion Inhibitors on Reinforced Concrete

Table XXII Weight Loss measurement

\begin{tabular}{|l|l|l|l|l|l|}
\hline Bar No. & Wt. Before testing(gms) & Wt. After testing(gms) & Bar No. & Wt. Before testing(gms) & Wt. After testing(gms) \\
\hline $\mathbf{1}$ & 360 & 360 & 15 & 358 & 358 \\
\hline $\mathbf{2}$ & 359 & 358.7 & 16 & 355 & 354 \\
\hline $\mathbf{3}$ & 343 & 342.5 & 17 & 356 & 356 \\
\hline $\mathbf{4}$ & 362 & 361.5 & 18 & 354 & 354 \\
\hline $\mathbf{5}$ & 338 & 338 & 19 & 354 & 353.7 \\
\hline $\mathbf{6}$ & 351 & 351 & 20 & 347 & 346.7 \\
\hline $\mathbf{7}$ & 353 & 353 & 21 & 346 & 346 \\
\hline $\mathbf{8}$ & 351 & 351 & 22 & 358 & 358 \\
\hline $\mathbf{9}$ & 357 & 357 & 23 & 362 & 361.6 \\
\hline $\mathbf{1 0}$ & 352 & 352 & 24 & 354 & 353.7 \\
\hline $\mathbf{1 1}$ & 357 & 357 & 25 & 358 & 356 \\
\hline $\mathbf{1 2}$ & 346 & 356 & 26 & 357 & 354 \\
\hline $\mathbf{1 3}$ & 358 & 354 & 353.4 & 358 & 352.5 \\
\hline $\mathbf{1 4}$ & & & 28 & 357 \\
\hline
\end{tabular}

\section{CONCLUSION}

From the study it can be concluded that surface applied corrosion inhibitors provides a protective layer to the reinforcement thereby protecting it from corrosion and increasing the durability of the structure. It proves that the use of surface applied corrosion inhibitors is an effective way to enhance the corrosion inhibition capacity of concrete. The control specimens showed a higher corrosion activity as compared to the Neem and Zinc coated specimens. Among the Organic and Inorganic Inhibitors, the organic inhibitors (Neem powder) showed better corrosion inhibition efficiency. The specimens with 4 coats of Neem showed the highest, i.e. $44 \%$ inhibition efficiency as compared to control specimen. The specimens with 4 coats of Zinc showed 6\% higher rate of corrosion as compared to control specimens. The specimens with 4 coats each of Neem and Zinc showed $14 \%$ inhibition efficiency when compared to control specimen. From the weight loss measurements, it can be concluded that the reinforcing bars of control specimens showed highest weight loss among all the specimens. This is due to chloride ingress, the chloride ions reacting with the ferrous ions to form ferric chloride and finally ferric chloride combining with the hydroxyl ions to form hydrated ferric hydroxide as corrosion product. On the other hand the Neem coated specimens showed very low weight loss nearly $0.2 \mathrm{gm}$ in 42 days which is better than the control specimen. The weight loss of Zinc coated specimens was also less as compared to control specimens.

Finally this type of technique of using surface applied corrosion inhibitors on reinforced steel in concrete can be used in various structures such as buildings, bridges, sewage pipes, marine structures, abutments \& piers, RCC roads which are subjected to harsh environmental conditions.

\section{REFERENCES}

1. I.A. Adejoro, F.K. Ojo, S.K. Obafemi, "Corrosion inhibition potentials of ampicillin for mild steel in hydrochloric acid solution", Journal of Taibah University of Science, 9 (2015). 196-202

2. Khadija M. E, Shimaa M. A, Hamedh A. Al L, "Green Methods for Corrosion Control", Corrosion Inhibitors, Principles and Recent Applications. 2017 http://dx.doi.org/10.5772/intechopen.72762

3. Pandian B R, Mohammad I, Seyedmojtaba G, Jahangir M, Mokthar C, Saeid K\& Afidah A R(2016): Reviews on Corrosion Inhibitors - A Short View, Chemical Engineer-ing Communications, DOI:10.1080/00986445.2016.1172485

4. Lisha C, Prof. M. R lingam, Dr S George, "Corrosion resistance of reinforced concrete with green corrosion inhibitors" International Journal of Engineering Science Invention Research \& Development; 2017,Vol. III(XI), pp. 687-691

5. P Pokorny, D Dobias, D Citek, "The influence of corrosion of zinc powder on mechanical properties of concrete" Ceramics-Silikaty,2016, 60(3), 195-199

6. Hong Ju, Zhen-Peng Kai, Yan Li, "Aminic nitrogen-bearing polydentate Schiff base compounds as corrosion inhibitors for iron in acidic media: A quantum chemical calculation" Corrosion Science, Vol. 50(3), pp. 865-871, 2008

7. G.M Akshatha, B.G.Jagadeesha Kumar, Dr. Pushpa H ,"Effect of corrosion inhibitors in reinforced concrete" International Journal of Innovative Research in Science, Engineering and Technology, Vol.4, Issue 8, 2015, pp. 6794-6801

8. A Zacharopoulou, E Zacharopoulou, G Batis (2014), "Protection Systems for Reinforced Concrete with Corrosion Inhibitors", Open Journal of Metal, 4, 86-92.

9. R Das, R Debbarma, "Effect of corrosion inhibitor on properties of concrete and mortar made with different admixtures" International Journal of Research in Engineering and Technology, 2013, vol. 2, Issue 3, pp.294-298

10. I Vyrides, E Rakanta, T Zafeiropoulou, G (2013), "Efficiency of Amino Alcohols as Corrosion Inhibitors in Reinforced Concrete" Open Journal of Civil Engineering, 3, pp. 1-8.

11. C. A. Loto, R. T. Loto and A. P. I. Popoola, "Effect of Neem leaf (Azadirachta indica) extract on the corrosion inhibition of mild steel in dilute acids" International Journal of Physical Sciences, 2011, Vol.6(9), pp. 2249-2257

Published By:

Blue Eyes Intelligence Engineering \& Sciences Publication

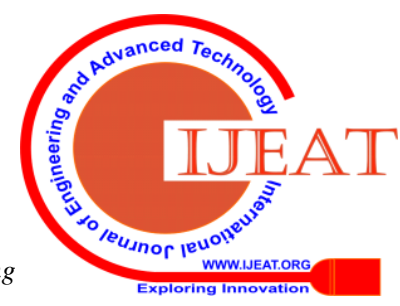


12. Sanjay K. Sharma, "Corrosion inhibition and adsorption properties of Azadirachta indica mature leaves extract as green inhibitor for mild steel in HNO3”, Green Chemistry Letters and Reviews,2010, Vol. 3, No. 1.

13. Broomfield J. P., (2006). "Corrosion of Steel in Concrete" 2nd ed.UK: Taylor \& Francis

14. Pierre R. Roberge, (2008) "Corrosion engineering, Principles and Practice", by The McGraw-Hill Companies

\section{AUTHORS PROFILE}

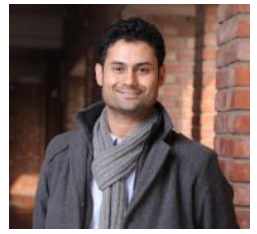

Mr. Nishant Kumar has B.Tech in Civil Engineering and M.Tech in Structural Engineering having total academic experience of more than 6 years with total industry experience of 2 years with Jaiprakash Associated Ltd. And Ambuja Cements Ltd. He has filed three patents on topics, "Method of inhibiting corrosion of a metallic reinforcement in a concrete structure using corrosion inhibiting composition", "A Composite Concrete Composition and Process of Preparation Thereof", "A Self-Compacting Concrete Mix". In addition, he has published 20 research papers. His areas of interest are concrete structures, Structural Dynamics, Concrete Technology, Steel Structures. Currently, he is working as an Assistant Professor , Department of Civil Engineering, Sharda University and has guided more than $20 \mathrm{M}$.Tech Thesis and 10 B.Tech Thesis.

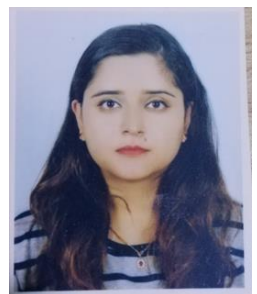

Ms. Bisakha Chalisey has completed her B.E in Civil Engineering from Lalitpur Engineering College, Institute of Engineering, Kathmandu, Nepal. She has over 3 years of work experience in industry: 1.5 years in Elite Construction Company as a Civil Engineer and 1.5 years in Jade Consult Pvt. Ltd. as a Civil Engineer. Her experience include procurement, estimation and costing, design and drawings of various roads and hydropower projects in Nepal. Currently, she is pursuing M.Tech in Structural Engineering from Sharda University. Also, she has published more than 3 research papers. Her areas on interest include Structural Analaysis, Steel Strcutures, Concrete Technology, Corrosion Inhibiors etc.

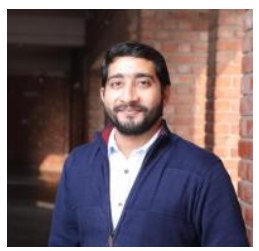

Mr. Sunil Saharan has completed his B.Tech in Civil Engineering from SBCET, Jaipur and his M.Tech degree in Structural Engineering from Thapar University, Patiala. He has over 2.5 years of teaching experience: One year teaching experience at MMU, Mullana and one year and six months teaching experience at,Bahra University, Shimla. Also, he has worked as site engineer at Ambit concrete Pvt. Ltd. His areas of interest are Self-compacting concrete, Active protection of RCC and SHM. Currently, he is working as an Assitant Professor in Department of Civil Engineering in Sharda University.

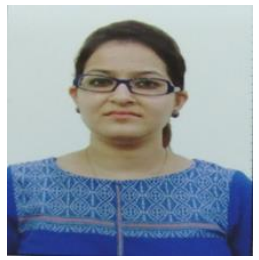

Ms. Megha Gupta has total academic experience of more than 6 years. Her qualifications include B.E in Civil Engineering and M.Tech in Structural Engineering. Throughout her career she has taught various subjects related to the field of Structural Engineering for B.Tech and M.Tech students. She has filed 2 patents on topics, "High strength concrete mix using quarry dust", and, "A high strength concrete composition". Additionally, she has published 12 research papers on various topics. She mainly focuses on Design of Structrues, Concrete Structures, Concrete Technology and Steel Strcutures. Currently, she is working as an Assistant Professor in Department of Civil Engineering in Sharda University and has guided over 9 M.Tech thesis and more than 15 B.Tech Thesis. 